\title{
40. LATE NEOGENE SILT AT THE SIERRA LEONE RISE (LEG 41 SITE 366): TERRIGENEOUS AND BIOGENOUS COMPONENTS
}

\author{
Dieter Futterer, Geologisch-Paläontologisches Institut der Universität Kiel, \\ Olshausenstr. 40/60, 23 Kiel, Federal Republic of Germany
}

Pelagic sediments normally (i.e., above $\mathrm{CCD}$, no contourites, etc.) contain only $5 \%-30 \%$ of material coarser than $63 \mu \mathrm{m}$. In order to properly interpret such sediments, the fine-grained material has to be considered as well. A number of previous studies on this subject were usually based on semiquantitative data such as that obtained from smear-slide examinations. Their results, however, are of limited value. Scanning electron microscopy, a method which has been applied with good success in elucidating diagenetic processes and structures of fine-grained sediments (Matter, 1974; Matter et al., 1975; Neugebauer, 1973, 1975; Schlanger et al., 1973; Wise, 1973; Wise and Weaver, 1974), should also provide useful studies of the fine-grained material.

This paper presents the preliminary results of an investigation of the silt-sized fraction $(2-63 \mu \mathrm{m})$ of a calcareous, pelagic sediment section by SEM examination. It tentatively gives a quantitative evaluation and interpretation of the constituent particle composition.

\section{REGIONAL SETTING AND SEDIMENTS}

The present study is based on core material recovered during DSDP Leg 41 on the Sierra Leone Rise at Site 366. The site is located on the eastern edge of the Sierra Leone Rise, an irregularly shaped, large, elongated plateau midway between the Mid-Atlantic Ridge and the African continent at $5^{\circ} 40^{\prime} \mathrm{N}$ and $19^{\circ} 51^{\prime} \mathrm{W}$. The water depth at Site 366 is 2860 meters.

Because of its geographic position (Figure 1), Site 366 was supposed to be isolated from terrigenous sediment supply, receiving only pelagic sedimentation of predominantly biogenic origin.

Only Neogene samples were selected in order to exclude any diagenetic alterations such as dissolution, crystallite overgrowth, and recrystallization or cementation. Other parallel investigations on Site 366 material (Diester-Haass, this volume; Futterer, this volume) indicate evident diagenetic modifications of fossil preservation that first occur in the late Miocene at a core depth of about 110 meters.

\section{MATERIAL}

If possible one sample per core section was taken from the uppermost six cores of Hole 366A. The same samples were used by Krasheninnikov and Pflaumann for foraminiferal stratigraphy, by Samtleben for analysis of Neogene coccolith assemblages, by Fütterer for stratigraphic distribution of calcareous dinoflagellates, and by Diester-Haass for coarse grain analyses (all this volume).

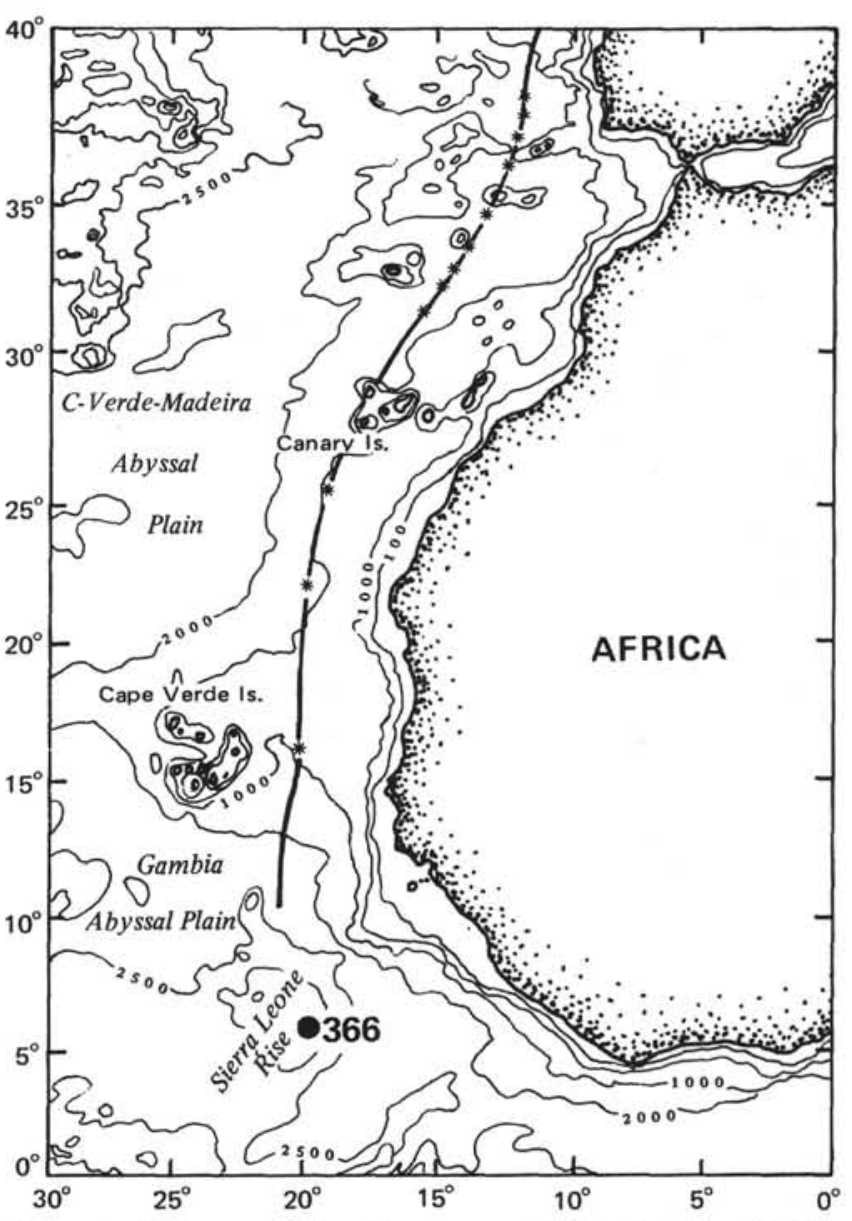

Figure 1. Index map showing geographic position and bathymetry of the Sierra Leone Rise and location of Site 366.

\section{METHODS}

Samples were wet sieved using a $63 \mu \mathrm{m}$ mesh sieve. For better disaggregation and cleaning of sedimentfilled foraminifera tests, the samples were treated with $\mathrm{H}_{2} \mathrm{O}_{2}$ prior to washing. Subsequently the fine material $<63 \mu \mathrm{m}$ was fractionated by sedimentation analyses into fractions of $\langle 2 \mu \mathrm{m}, 2-6 \mu \mathrm{m}, 6-20 \mu \mathrm{m}$, and 20-63 $\mu \mathrm{m}$ using a modified Atterberg method. All fractions were dried at $60^{\circ} \mathrm{C}$ and weighed and finally summed up giving $100 \%$ of weight.

Before drying, an appropriate quantity of the silt fractions (2-6 $\mu \mathrm{m}, 6-20 \mu \mathrm{m}, 20-63 \mu \mathrm{m})$ was mounted by wet sedimentation on SEM stubs using photographic paper as adhesive for the two coarser fractions. The fine-silt fraction $(2-6 \mu \mathrm{m})$ was suspended in a suitable concentration and a few drops were mounted on a glass 
cover slide. This method is described in more detail by Fütterer (in preparation). Subsequently the samples were coated twice with carbon and gold-palladium for SEM examination.

From each silt fraction some 20 overlapping photographs were made by SEM and grouped into a mosaic. The magnification depended on the size of the fractions: 500 times for the $20-63 \mu \mathrm{m}$ fraction, 1000 times $(6-20 \mu \mathrm{m})$, and 2000 times $(2-6 \mu \mathrm{m})$. Depending on their density of distribution some 400 to 1000 particles per fraction were counted and analyzed in the SEM pictures.

The carbonate content of each fraction was determined by IR spectroscopy of $\mathrm{CO}_{2}$ liberated by $\mathrm{HCl}$ addition.

\section{RESULTS}

Grain size: The grain size distribution of selected samples (Figure 2) does not show any remarkable trends, but displays quite large proportions of sand sized material $(>63 \mu \mathrm{m})$. On the whole, a slight downward decrease of the coarse fraction is to be observed from Zone NN-21 to Zone NN-19. A sudden increase of coarse material occurs between the Zone $\mathrm{NN}-17$ and Zone NN-16. The relative proportion of the single fractions does not show significant variations.

Carbonate content: The carbonate content of all fractions shows the same trends (Figure 3). Generally, there is an evident increase in carbonate content with increasing depth of core though some significant fluctuations can be distinguished.

However, most significant is the fact that lowest carbonate values are concentrated not in the $<2 \mu \mathrm{m}$ fraction but in the 2-6 $\mu \mathrm{m}$ silt fraction on the Sierra Leone Rise during large parts of the Pleistocene. This is different from normal pelagic sediments where carbonate content and grain size are more or less parallel.

Components: The distribution of the main components is shown in Figure 4. The general appearance of the fractions is given on Plates 1 and 2 . As expected, foraminifera-derived particles dominate the coarse silt fraction $(20-63 \mu \mathrm{m})$ and are the most abundant group in the 6-20 $\mu \mathrm{m}$ fraction as well. On the other hand, only insignificant proportions are found in the 2-6 $\mu \mathrm{m}$ fraction. The absolute amounts within particular fractions vary insignificantly.

The abundance of coccoliths is inversely related to that of foraminifera: highest portions occur in the 2-6 $\mu \mathrm{m}$ fraction, low portions within the $6-20 \mu \mathrm{m}$ fraction. They are totally absent in the coarse silt fraction. Additionally, calcareous dinoflagellates (mostly thoracospharids) are present with minor quantities in all fractions, but are most abundant within the 6-20 $\mu \mathrm{m}$ fraction.

All remaining groups of organisms which are present in quantitatively insignificant amounts, are classed together with all undefined biogenic particles to one group of "miscellaneous biogenic particles." Among this group, diatoms are of special interest because fresh water types (Melosira granulata) are present in Samples $366-1-1,73-75 \mathrm{~cm}$ to $366 \mathrm{~A}-2$, CC (compare with Schrader, this volume). They amount up to $1 \%$ of a particular fraction. These observations are corroborated by the occurrence of opal phytoliths in Samples 366A-1-1, 73-75 cm and 366A-2-2, 68-70 cm (compare with Schrader, this volume). Both groups are of terrigenous origin. Most probably, they are supplied as aeolian dust from the African continent.

The nonbiogenic components are identical with terrigenous material. Two groups are distinguished: (1) quartz unequivocally determined, although features of sand-sized quartz grain surfaces (Krinsley and Doornkamp, 1973) are only of limited value when analyzing silt-sized particles; (2) "detritus" contains all remaining nonbiogenic particles but quartz (mainly mica, clay aggregates, unidentified quartz, and negligible quantities of unspecified carbonate).

Quartz is present in all samples, showing only minor portions in the 20-63 $\mu \mathrm{m}$ fraction. A distinct maximum occurs in the $6-20 \mu \mathrm{m}$ fraction, whereas smaller amounts are present in the $2-6 \mu \mathrm{m}$ fraction. This might be due to difficulties of determination, since the portion of the detritus, as defined above, is increasing in a similar relation as the quartz content is decreasing. In general, the quartz content is nearly constant from Zone NN-21 to Zone NN-17, although a slight fluctuation is present about the Pleistocene/Pliocene boundary from Zone NN-19 to Zone NN-18. The most striking variation, however, happens from Zone NN-17 to Zone NN-16 within the late Pliocene where the quartz content decreases abruptly to minimal values. This agrees quite well with corresponding events of broader significance (Ciaranfi and Cita, 1973; Schlanger and Douglas, 1974).

The quartz is considered to be of aeolian origin. This consideration is based on size distribution, particle shape, and surface ultrastructure as well as of the regional setting of the Sierra Leone Rise, i.e., its isolation from surrounding sea bottom. This interpretation is supported by the abundant occurrence of fresh water diatoms and opal phytoliths within late Pleistocene samples.

"Detritus," such as defined above, shows increasing amounts with decreasing grain size.

In regard of the absolute abundances of components given in Figure 4, it should be stressed that all percentage data of components are grain number proportions whereas the carbonate content (Figure 3) and the grain size distribution (Figure 2) represent weight percentages.

Grain number and weight percentages, however, are only conditionally equal or comparable due to different reasons which are not discussed in detail here. Some differences result from heterogeneous composition, from particle size and shape, as well as from different specific gravity of particular mineral phases. Partly, these variations are compensated by the fractionation process during sedimentation analyses. But this is only the case if the grain size spectrum of each grain class investigated is completely covered by each component. This has been only rarely realized.

At least quartz and coccoliths do not agree with this demand in the present study. The quartz is most abundant within the 2-6 $\mu \mathrm{m}$ and 6-20 $\mu \mathrm{m}$ fractions, but does not cover the whole spectrum of these grain 


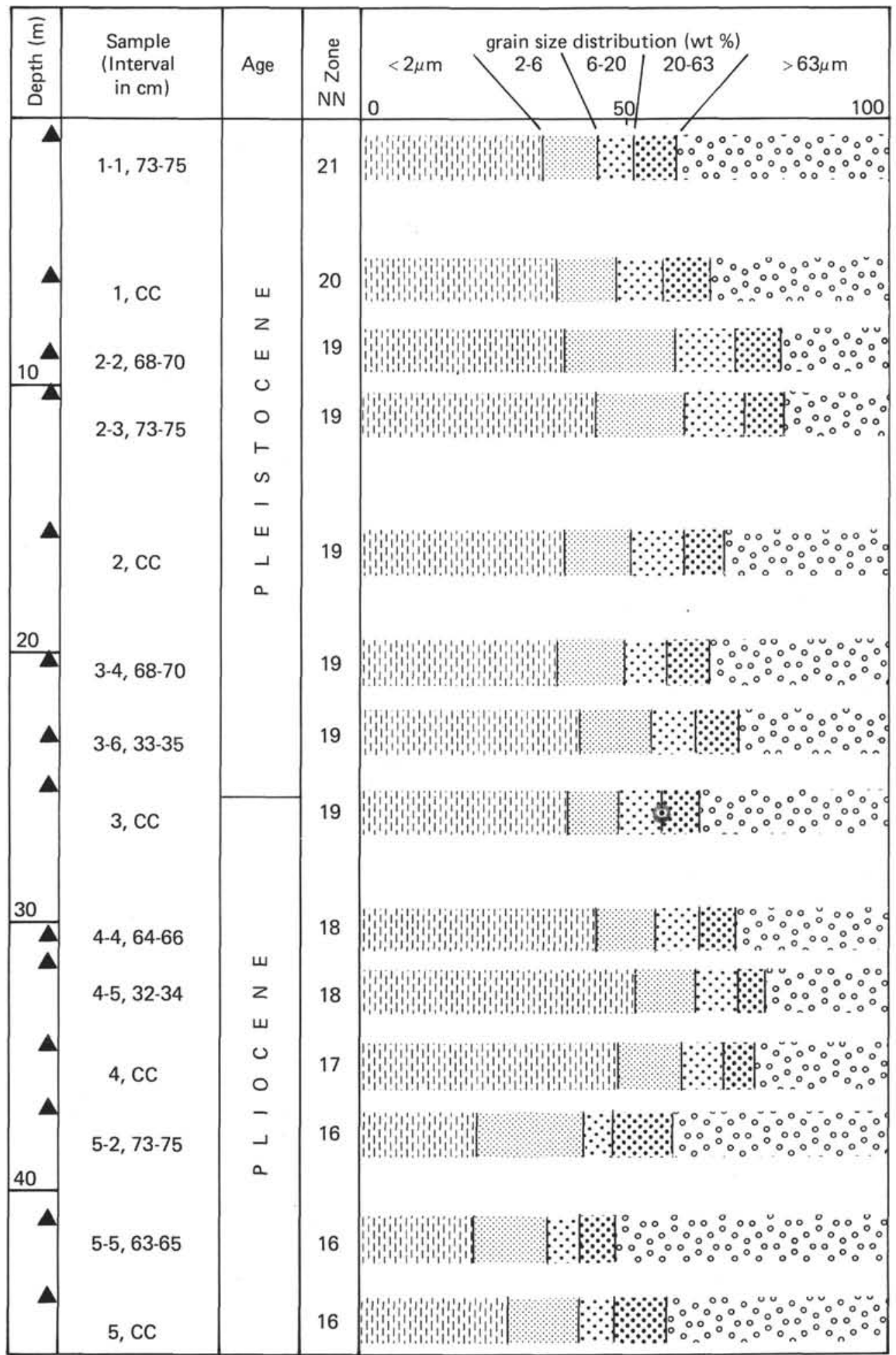

Figure 2. Grain size distribution of selected Pleistocene/Pliocene samples of Hole $366 \mathrm{~A}$ from the Sierra Leone Rise.

classes. Because of their aeolian origin, the quartz grains do not occur in equal amounts at sizes of $15-20$ $\mu \mathrm{m}$ (Plate 1, Figures 2, 5). The coccoliths are a mixture of different species. Each species has its own size distribution depending on the species itself and on ecological conditions. Therefore all species are extremely disproportionate in their distribution within the silt fractions (Plate 2, Figures 2, 3, 5, 6). As a result, there is a discrepancy between carbonate content, expressed in weight percentages, and content of total biogenic components, expressed in grain number percentages, within the 2-6 $\mu \mathrm{m}$ and the 6-20 $\mu \mathrm{m}$ fractions so that all values of total biogenic components are some $10 \%$ too high. This has to be kept in mind if 


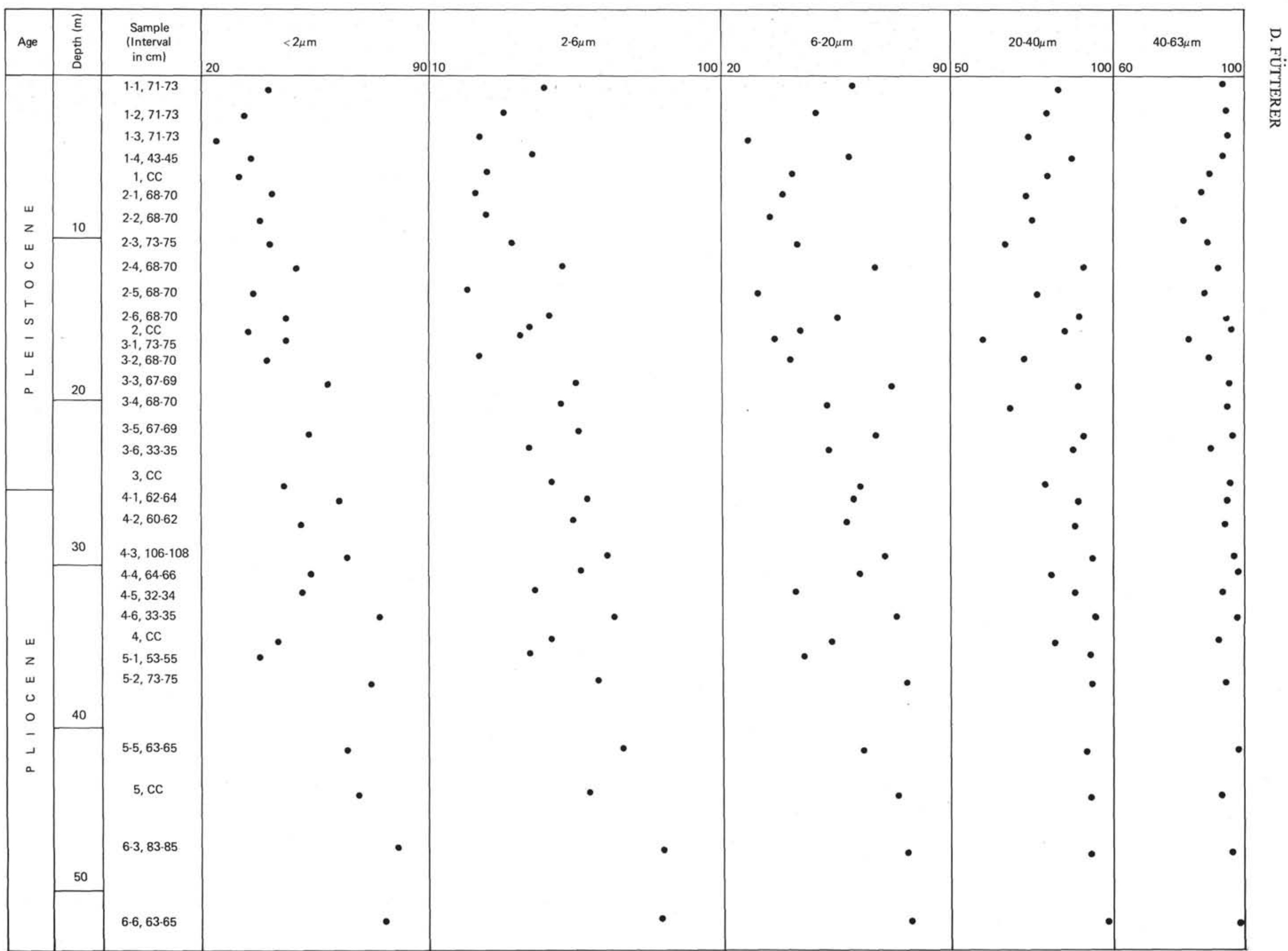

Figure 3. Carbonate content in weight percentages $\mathrm{CaCO}_{3}$ of fractionated samples of Hole $366 \mathrm{~A}$ from the Sierra Leone Rise. 


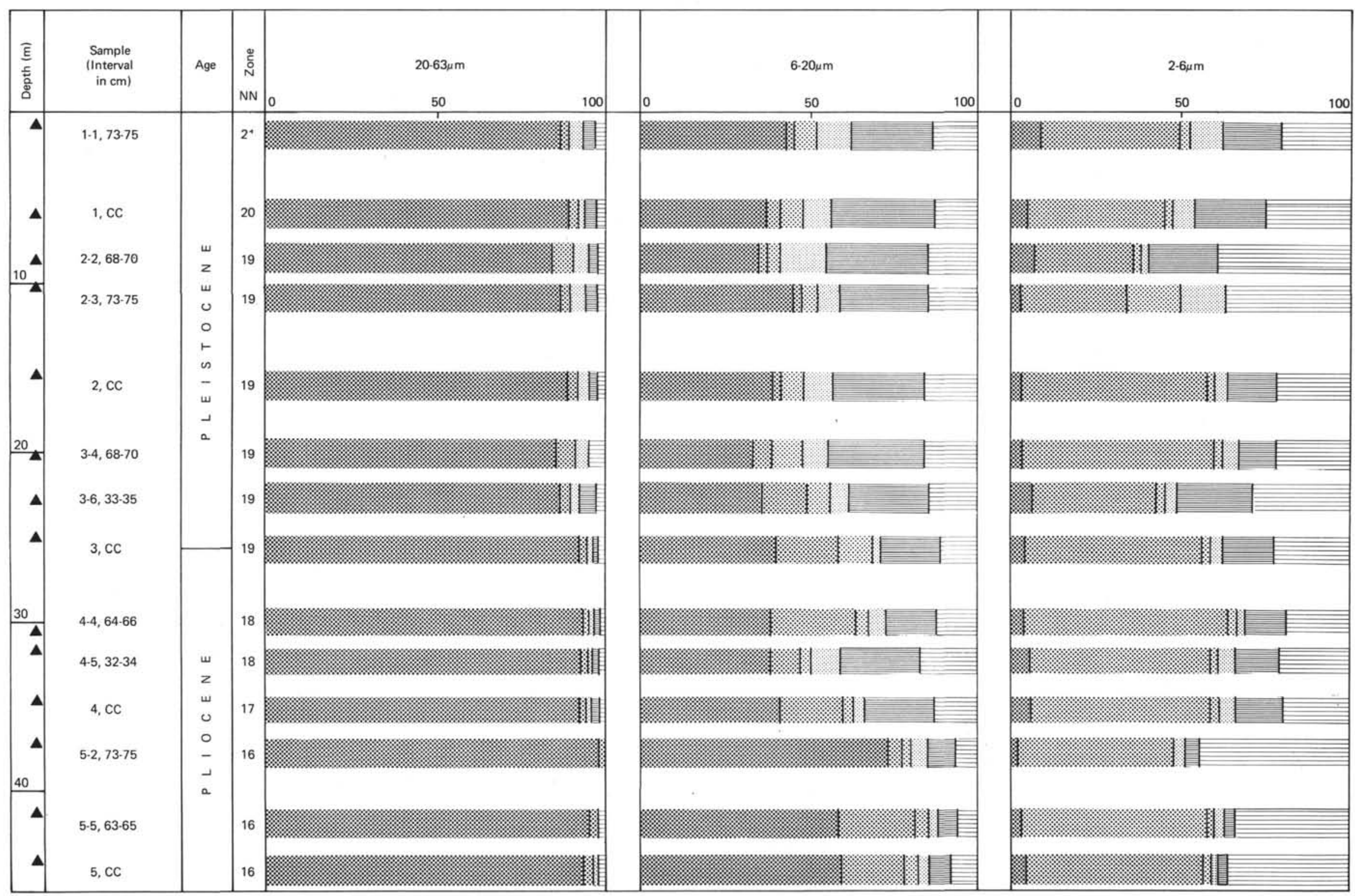

Figure 4. Quantitative proportions of main constituent particle composition of the silt-sized fractions of samples from Sierra Leone Rise. Note that all values are given as grain number proportions. $1=$ foraminifera ; $2=$ coccoliths $3=$ calcareous dinoflagellates 3 ; $4=$ miscellaneous biogenic particles _. ; 5 = quartz 
any further calculation is done as, for example, calculations of accumulation rates of particular components.

\section{CONCLUSIONS}

An examination by scanning electron microscopy of the silt-sized fraction of selected Pleistocene and late Pliocene samples from the Sierra Leone Rise shows that planktonic organisms, such as foraminifera, coccoliths, and calcareous dinoflagellates in variable proportions within particulate fractions, are the main biogenic sediment contributors.

During long periods of the Pleistocene and Pliocene as well, aeolian sedimentation played an important role. This is evident from fine-grained quartz distribution, as well as from fresh water diatoms and opal phytoliths which are present within these sediments in significant numbers. Accordingly, sedimentation on the Sierra Leone Rise is not purely pelagic but mixed with distinct amounts of terrigenous aeolian material which corresponds to the major sediment proportion of the noncarbonate fraction. By analogy to modern conditions the aeolian material originated from the African continent.

Sample intervals are not sufficient to give further detailed climatic interpretations. Opal phytoliths and fresh water diatoms may indicate climatic conditions such as present south of the present Sahara. This regime would be active since the early Pleistocene (Samples 366A-1-1, 73-75 cm to 366A-2, CC).

The Pleistocene/Pliocene boundary is not marked by any alteration of the bulk sediment or of its components. An abrupt change in sediment composition is obvious between Zone NN-17 and Zone $\mathrm{NN}-16$. This may be controlled by profound changes of climatic conditions in the aeolian dust source area.

\section{ACKNOWLEDGMENTS}

The author would like to thank U. Pflaumann and E. Seibold for providing samples and extensive shipboard data. C. Samtleben and M. Sarnthein contributed much information by numerous helpful discussions. Technical help by A. Dohrmann, W. Reimann, and U. Schuldt is gratefully acknowledged. Finally the author acknowledges financial support by the "Deutsche Forschungsgemeinschaft."

\section{REFERENCES}

Ciaranfi, N. and Cita, M.B., 1973. Paleontological evidence of changes in the Pliocene climates. In Ryan, W.B.F., Hsu, K.J., et al., Initial Reports of the Deep Sea Drilling Project, Volume 13: Washington (U.S. Government Printing Office), p. 1387-1399.

Krinsley, D.H. and Doornkamp, J.C., 1973. Atlas of quartz sand surface textures: Cambridge (Cambridge University Press), p. 91.

Matter, A., 1974. Burial diagenesis of pelite and carbonate deep sea sediments from the Arabian Sea. In Whitmarsh, R.B., Weser, O.E., Ross, D.A., et al., Initial Reports of the Deep Sea Drilling Project, Volume 23: Washington (U.S. Government Printing Office), p. 421-469.

Matter, A., Douglas, R.G., and Perch-Nielsen, K., 1975. Fossil preservation, geochemistry, and diagenesis of pelagic carbonates from Shatsky Rise, Northwest Pacific. In Larson, R.L., Moberly, R., et al., Initial Reports of the Deep Sea Drilling Project, Volume 32: Washington (U.S. Government Printing Office), p. 891-921.

Neugebauer, J., 1973. The diagenetic problem of chalk: N. J. Geol. Paläont. Abh., v. 143, p. 223-245.

1975. Fossil-Diagenese in der Schreibkreide: Coccolithen: N. J. Geol. Paläont. Mh., p. 489-502.

Schlanger, S.O. and Douglas, R.G., 1974. The pelagic oozechalk-limestone transition and its implication for marine stratigraphy. In Hsu, K.J. and Jenkyns, H.C. (Eds.), Pelagic sediments: on land and under the sea: Spec. Publ. Int. Assoc. Sediment., v. 1, p. 117-148.

Schlanger, S.O., Douglas, R.G., Lancelot, Y., Moore, T.C., and Roth, P.H., 1973. Fossil preservation and diagenesis of pelagic carbonates from the Magellan Rise, Central North Pacific Ocean. In Winterer, E.L., Ewing, J.I., et al., Initial Reports of the Deep Sea Drilling Project, Volume 17: Washington (U.S. Government Printing Office), p. $407-427$.

Wise, S.W., 1973. Calcareous nannofossils from cores recovered during Leg 18, Deep Sea Drilling Project: Biostratigraphy and observations of diagenesis. In Kulm, L.D., von Huene, R., et al., Initial Reports of the Deep Sea Drilling Project, Volume 18: Washington (U.S. Government Printing Office), p. 569-615.

Wise, S.W. and Weaver, F.M., 1974. Chertification of oceanic sediments. In Hsu, K.J. and Jenkyns, H.C. (Eds.), Pelagic sediments: on land and under the sea: Spec. Publ. Int. Assoc. Sediment., v. 1, p. 301-326. 



\section{PLATE 1}

Scanning electron micrographs of the silt sized fractions from natural sediments; (10 kv; scale bars $40 \mu \mathrm{m}$ ).

Figures 1-3 Sample 366A-1-1, 73-75 cm (Emiliania huxleyi Zone, NN 21).

1. 20-63 $\mu \mathrm{m}$ fraction foraminifera fragments are the greater portion; $52815,400 \times$.

2. 6-20 $\mu \mathrm{m}$ fraction with increasing portion of quartz-mica-detritus; 50361, $800 \times$.

3. 2-6 $\mu \mathrm{m}$ fraction, coccoliths and quartz-micadetritus are the main components; 50342, $1600 \times$.

Figures 4-6 Sample 366A-1, CC (Gephyrocapsa oceanica Zone, NN 20).

4. 20-63 $\mu \mathrm{m}$ fraction nearly totally composed of foraminifera fragments; $48421,400 \times$.

5. 6-20 $\mu \mathrm{m}$ fraction; quartz detritus becomes most significant; note the striking differences in particle size of foram fragments and quartz; 46794, 800X.

6. 2-6 $\mu \mathrm{m}$ fraction; main components are coccoliths and quartz-mica-detritus; a minor but significant component are diatom fragments; $46876,1600 \times$. 
PLATE 1
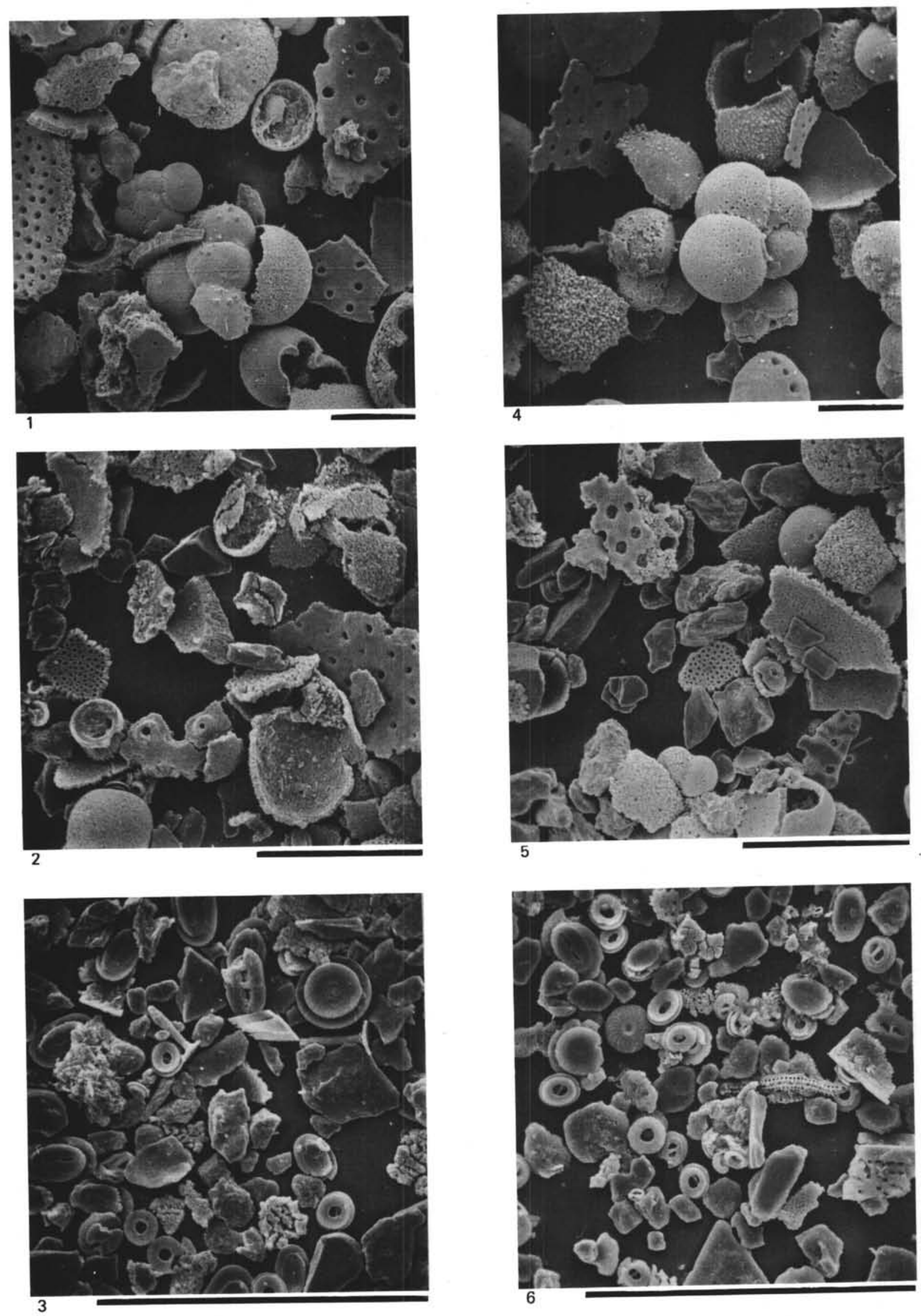


\section{PLATE 2}

Scanning electron micrographs of the silt sized fractions of natural sediments; (10 kv, scale bars $40 \mu \mathrm{m}$ ).

Figures 1-3 Sample 366A-3, CC (Pseudoemiliania lacunosa Zone, NN 19).

1. 20-63 $\mu \mathrm{m}$ fraction nearly totally composed of foraminifera fragments; $48466,400 \times$.

2. 6-20 $\mu \mathrm{m}$ fraction; the biogenic portion is composed of foram fragments, larger types of coccoliths and calcareous dinoflagellates; detritus, mostly quartz, is present showing remarkable smaller grain size than the biogenic particles; 47039, $800 \times$.

3. 2-6 $\mu \mathrm{m}$ fraction which is dominated by coccoliths and quartz-mica-detritus; 47139, 1600X.

Figures 4-6 Sample 366A-5-5, 63-65 cm (Discoaster surculus Zone, NN 16).

4. 20-63 $\mu \mathrm{m}$ fraction entirely composed of foraminifera fragments; $52772,400 \times$.

5. $6-20 \mu \mathrm{m}$ fraction which is nearly entirely composed of biogenic components; note that foram fragments show increasing disintegration and dissolution; 50800, $800 \times$.

6. 2-6 $\mu \mathrm{m}$ fraction composed predominantly of coccoliths and discoasters and of mixed aggregates of clay minerals and undefinable biogenic debris; $48629,1600 \times$. 
PLATE 2
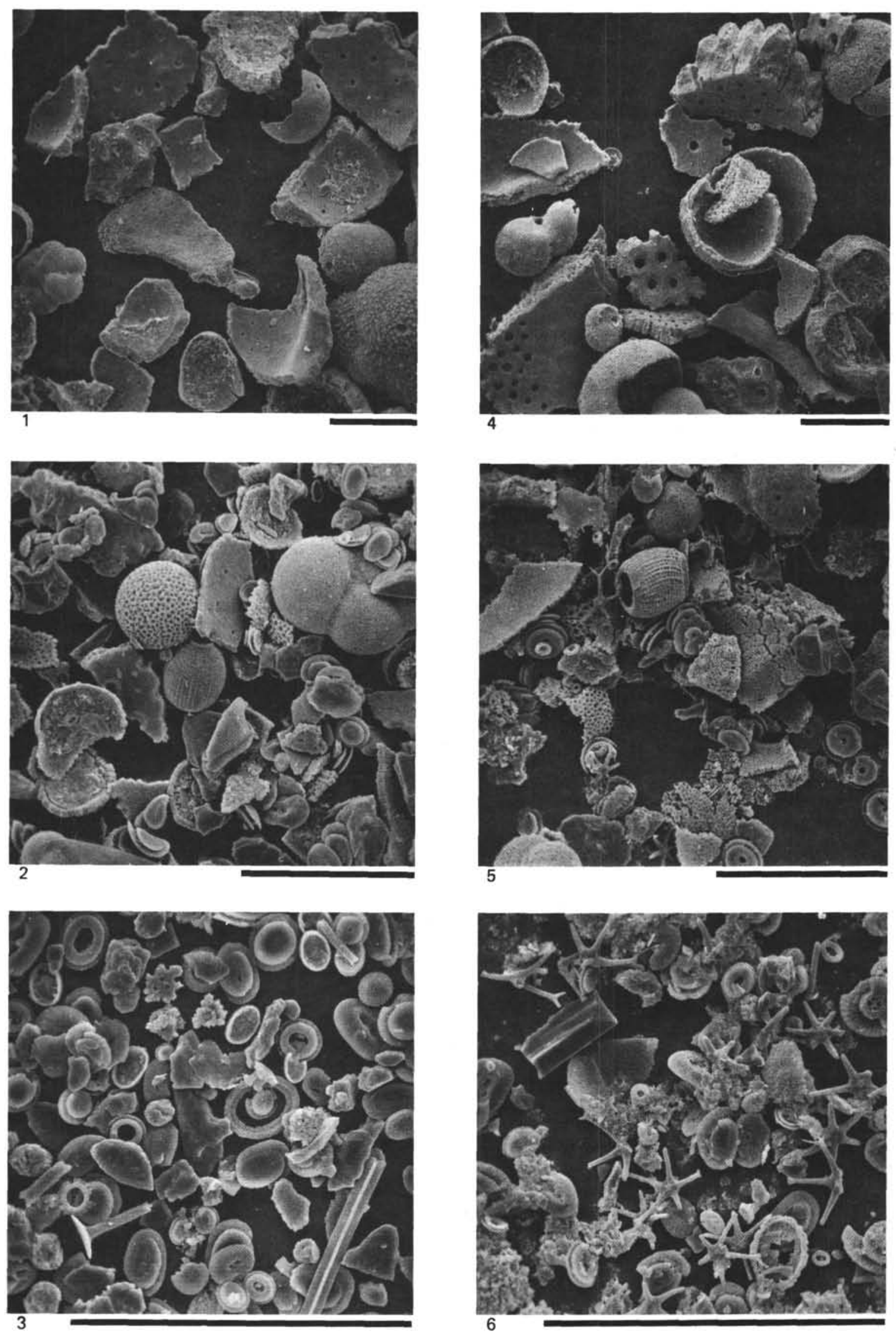